\title{
Sebaceous Adenocarcinoma in a Cat
}

\section{K. A. TERIM KAPAKINN ${ }^{1}$, F. BOZKURT ${ }^{2}$, R. HAZIROĞLU ${ }^{3}$}

${ }^{1}$ Department of Pathology, Faculty of Veterinary Medicine, Atatürk University, Erzurum, Turkey ${ }^{2}$ Department of Pathology, Faculty of Veterinary Medicine, Afyon Kocatepe University, Afyon, Turkey ${ }^{3}$ Department of Pathology, Faculty of Veterinary Medicine, Ankara University, Ankara, Turkey

Received June 7, 2007

Accepted November 15, 2007

\begin{abstract}
Terim Kapakin K.A., F. Bozkurt, R. Haziroğlu: Sebaceous Adenocarcinoma in a Cat. Acta Vet. Brno 2008, 77: 123-125.

In this study, the sebaceous gland adenocarcinoma was presented in the external auditory canal of a 10-year-old female tabby cat. There were three tumoural masses located macroscopically in the external auditory canal in the dimensions of $0.2 \times 0.5,0.3 \times 0.5$, and $0.1 \times 0.1 \mathrm{~cm}$, and they were of hard consistency. The cut sections of these tumoural masses were of multilobular appearance and ranged from white to yellow colour. Histopathological examination revealed the presence of oval or round shaped tumour cells with hyperchromatic nuclei and cytoplasmic lipid vacuoles that were divided by fibrous tissue into lobules. Atypism and mitosis were not significant. Irregular necrotic areas and mononuclear cell infiltrations composed of lymphocytes and histiocytes were also observed. In conclusion, our laboratory service confirms that the sebaceous gland adenocarcinoma is a rarely occurring tumour in cats with specific histopathological lesions.
\end{abstract}

Cat, external auditory canal, sebaceous carcinoma, pathology

Tumours of the sebaceous glands are reported in all domestic animals, more frequently in old cats and dogs (Strafuss 1976; Vail et al. 1996). They are classified as hyperplasia, epithelioma, glandular adenoma, and carcinoma according to their histological features and growth (Goldschmidt and Hendrick 2002; Gross et al. 2005; Max's House 2005). Among tumours of the sebaceous glands, adenomas are observed frequently in dogs (Scott and Anderson 1990), whereas they are not so frequent in cats (Scott and Anderson 1991). However, carcinomas are rare both in cats and dogs (McMartin and Gruhn 1977; Gross et al. 2005; Max's House 2005). The sebaceous glands' tumours constitute approximately $8 \%$ of all skin tumours in the canine (Scott and Anderson 1991; Gross et al. 2005; Max's House 2005) and 2.3 - 4.4\% in the feline (Scott 1980; Gross et al.2005; Max's House 2005) species. The objective of this report was to present a rare and unique case of sebaceous adenocarcinoma confirmed histopathologically in a cat.

\section{Case Description}

Between 1980 and 2006, 405 cats for necropsy and 305 biopsies from cat tissues for histopathological examination were referred to the Department of Pathology, Faculty of Veterinary Medicine, University of Ankara. Among these examinations, only one was revealed to be sebaceous adenocarcinoma. Study materials were biopsies of masses from the external auditory canal of a 10-year-old female tabby cat. Tissue samples were fixed in $10 \%$ buffered formaldehyde, subjected to routine tissue processing, and embedded in paraffin. Tissue sections prepared from paraffin blocks at a thickness of $5 \mu$ were stained with the specific haematoxylin-eosin (HE) and Oil red O.

Address for correspondence:

Dr. Kubra Asena Terim Kapakin

Department of Pathology, Faculty of Veterinary Medicine

Atatürk University, Erzurum 25700, TURKEY
Phone: +90-442-631 4193

Fax: +90-442-631 4188

E-mail: kbraterim@yahoo.com, kbraterim@gmail.com

http://www.vfu.cz/acta-vet/actavet.htm 


\section{Results}

Macroscopic examination revealed the presence of three tumoural masses with hard consistency located in the external auditory canal in the dimension of $0.2 \times 0.5$, $0.3 \times 0.5$. They had multilobular appearance in colour varying from white to yellow. In histopathological examination, there were oval or round shaped tumour cells with hyperchromatic nuclei and cytoplasmic lipid vacuoles. The masses were divided by fibrous tissue into lobules (Plate XII, Fig. $1 \mathrm{a}-\mathrm{b}$ ). Atypism and mitosis were infrequent. In addition to irregular necrotic areas, mononuclear cell infiltrations composed of lymphocytes and histiocytes were also observed. Staining with the special Oil red-O stain revealed that cytoplasmic vacuoles were lipid vacuoles (Plate XIII, Fig. 1 c-d).

\section{Discussion}

Breed- or age-related predisposition to tumours of the sebaceous glands has not been confirmed in cats. However, these tumours are common among cats at the age of $8-15$ (Goldschmidt and Hendrick 2002; Gross et al. 2005). Benign or malign ear tumours are also reported to be common in cats between the ages of 7 - 11 (Ter Haar 2005). The age of cat in this case is in agreement with current literature.

In general, tumours of the sebaceous glands are located in the head, abdomen or thorax regions (Strafuss 1976; Goldschmidt and Hendrick 2002; Sozmen et al. 2002). Carcinomas of the sebaceous glands are also localized in the head, thorax, and perineal region in cats. Sebaceous carcinomas are mostly local, and rarely metastasize with regional lymph nodes and lymphatics (Goldschmidt and Hendrick 2002; Gross et al. 2005). Benign or malign ear tumours are local and do not metastasize (London et al. 1996). In the presented case, tumoural masses were limited to the external auditory canal.

The excised sections of tumours of the sebaceous glands are divided into small lobules by a thin layer of connective tissue and in the range of white to pale yellow colour (Suckow et al. 2002). Tumours are divided by fibrovascular connective tissue into lobules of varying dimensions. These lobules are composed of round or oval shaped tumour cells that display a medium level of pleomorphism and that have large hyperchromatic nuclei, pink coloured cytoplasm, a varying number of cytoplasmic lipid vacuoles and a small number of irregular mitotic figures (Goldschmidt and Hendrick 2002; Suckow et al. 2002; Gross et al. 2005). Both the macroscopic and the microscopic findings corroborated this case to be sebaceous carcinoma.

External auditory canal tumours, ceruminous glandular adenocarcinomas, mast cell tumours, rhabdomyosarcomas, papillomas and adenomas of the sebaceous glands are commonly observed tumoural cases in cats (Rogers 1988). However, no previous report exists on the observation of sebaceous adenocarcinoma in the external auditory canal in cats. During 16 years of service, 405 necropsy and 305 biopsy materials pertaining to cats were analysed at our department. Of these materials, only four were related to ear lesions. One case was reported to be sebaceous adenocarcinoma in the external auditory canal. This report reveals that sebaceous adenocarcinoma rarely occurs in cats with unique histopathological lesions.

\section{Sebaceózní adenokarcinom u koček}

V této studii je popisován sebaceózní adenokarcinom ve vnějším zvukovodu 10leté mourovaté kočky. Ve vnějším zvukovodu byly makroskopicky zjištěny 3 tumorózní masy o rozměrech $0,2 \times 0,5,0,3 \times 0,5$, a $0,1 \times 0,1 \mathrm{~cm}$ a tuhé konzistence. Řezy těchto tumorózních mas měly multilobulární vzhled a bílou až žlutou barvu. Histopatologickým vyšetřením byla zjištěna přítomnost tumorózních buněk oválného nebo kulatého tvaru. Buňky byly od- 
děleny fibrózní tkání do lobulů, měly hyperchromatická jádra a tukové vakuoly v cytoplasmě. Nebyl zjištěn častý výskyt mitóz a atypických buněk. Byly pozorovány nepravidelné nekrotické oblasti a infiltrace mononukleárními buňkami, tvořená lymfocyty a histiocyty. V závěru laboratoř potvrzuje, že sebaceózní adenokarcinom je u koček vzácně se vyskytujícím tumorem se specifickým histopatologickým nálezem.

\section{References}

GOLDSCHMIDT MH, HENDRICK MJ 2002: Tumors of the skin and soft tissues. In: Meuten DJ (Ed.). Tumors in Domestic Animals. $4^{\text {th }}$ ed. Iowa State Press, pp. 64-67

GROSS TL, IHRKE PJ, WALDER EJ, AFFOLTER VR 2005: Epithelial Neoplasms and Other Tumors. Section 2, Part I. In: Skin Diseases of the Dog and Cat: Clinical and Histopathologic Diagnosis. $2^{\text {nd }}$ ed. Blackwell Publishing, pp. 641-654

LONDON CA, DUBILZEIG RR, VAIL DM, OGILVIE GK, HAHN KA, BREWER WG, HAMMER AS, O'KEEFE DA, CHUN R, MCENTEE MC, MCCAW DL, FOX LE, NORRIS AM, KLAUSNER JS 1996: Evaluation of dogs and cats with tumors of the ear canal: 145 cases (1978 - 1992). J Am Vet Med Assoc 208: 1413-1418

MAX'S HOUSE 2005: Tumors of the skin and subcutaneous tissues.

http://maxshouse.com/tumors_of the_skin.htm Access date: July 16, 2006

MC MARTIN DN, GRUHN RF 1977: Sebaceous carcinoma in a horse. Vet Pathol 14: 532-534

ROGERS KS 1988: Tumors of the ear canal. Vet Clin N Am-Equine Pract 18: 860

SCOTT DW 1980: External ear disorders. J Am Anim Hosp Assoc 16: 426-433

SCOTT DW, ANDERSON WI 1990: Canine sebaceous gland tumors: a retrospective analysis of 172 cases. Canine Pract 15: 19-21, 24-27

SCOTT DW, ANDERSON WI 1991: Feline sebaceous gland tumors: a retrospective analysis of nine cases. Feline Pract 19: 16-18, 20-21

SOZMEN M, BROWN PJ, EVESON JW 2002: Sebaceous carcinoma of the salivary gland in a cat. J Vet Med A 49: $425-427$

STRAFUSS AC 1976: Sebaceous gland adenomas in dogs. J Am Vet Med Assoc 15: 640-642

SUCKOW MA, REBELLATTO MC, SCHULMAN AA, HOGENESCH H 2002: Sebaceous adenocarcinoma of the external auditory canal in a New Zealand white rabbit. J Comp Pathol 127: 301-303

TER HAAR G 2005: Diseases of the outer ear. Surgery Iventa. 30 ${ }^{\text {th }}$ World Congress of the Word Small Animal Veterinary Association. May 11 - 14, Mexico City, Mexico

VAIL MD, WITHROW SJ 1996: Tumors of the skin and subcutaneous tissues. In: WITHROW SJ, MACEWEN EG (Eds). Small Animal Clinical Oncology. $2^{\text {nd }}$ ed., W.B. Saunders Company. Philadelphia, pp. 167-191 

Plate XII

Terim Kapakin K. A. et al.: Sebaceous ... pp. 123-125
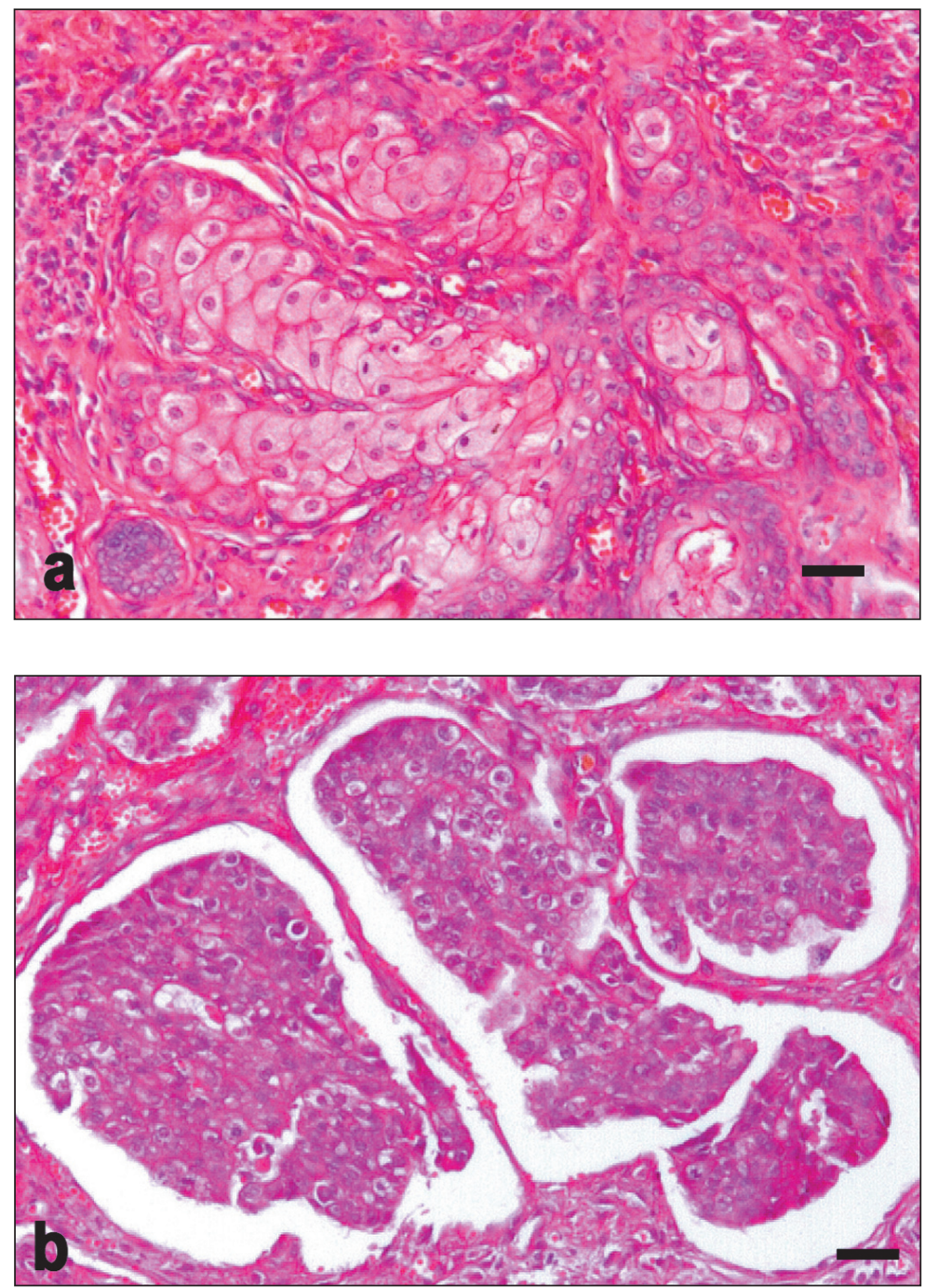

Fig. 1. Lobules containing the neoplastic cell, surrounded by a fibrose stroma. (a-b) HE, $\times 100$; 

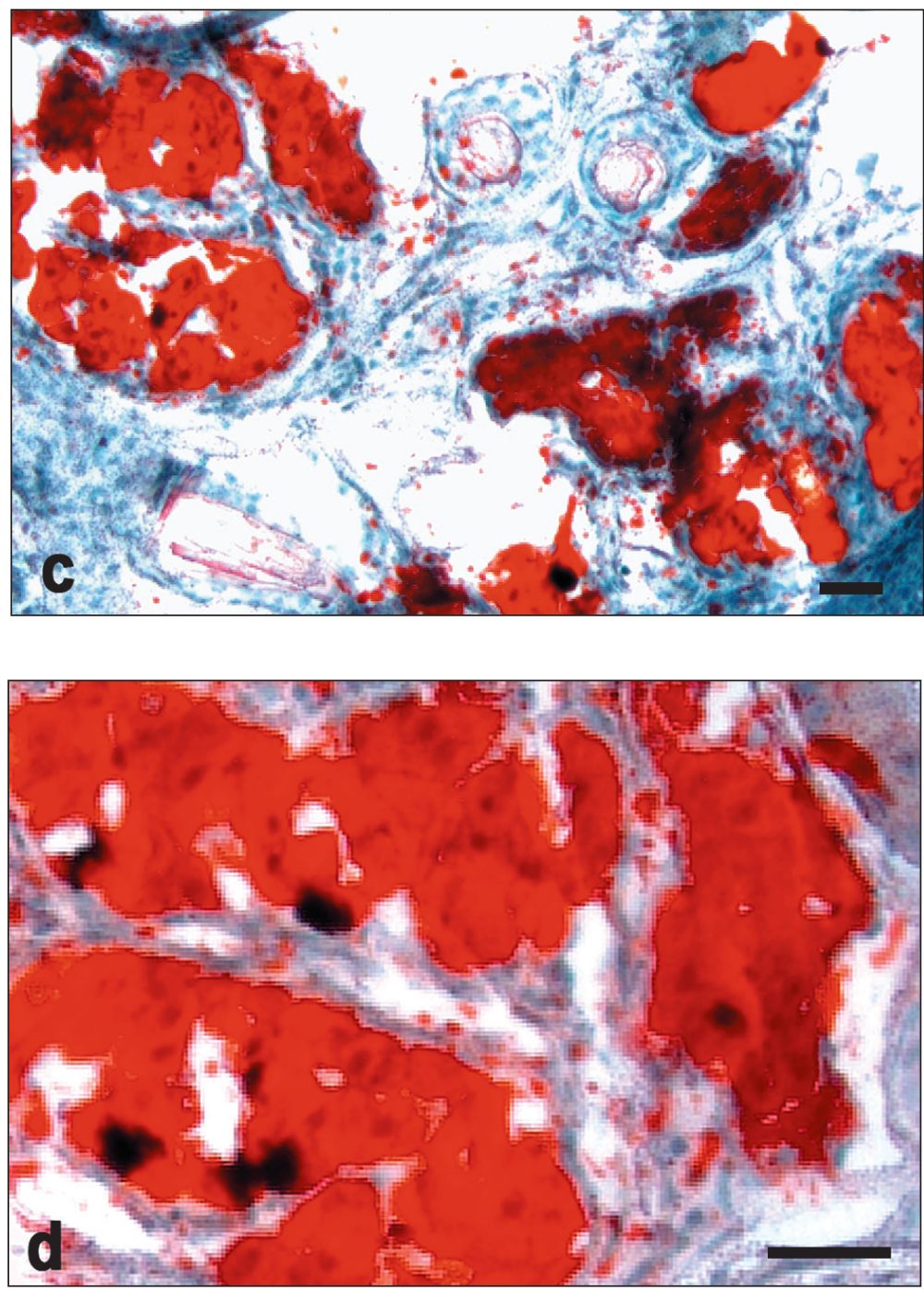

Fig. 1. Lobules containing the neoplastic cell, surrounded by a fibrose stroma; (c) Oil Red $\mathrm{O}, \times 100 ;$ (d) Oil Red O $\times 400$. Bar $=100 \mu \mathrm{m}$ 